\title{
SER imigrante, ESTAR colono: o processo de transformação dos imigrantes em colonos na Província do Paraná
}

\author{
BE immigrant, Be colonist: the transformation process of \\ immigrants in colonists in the province of Paraná
}

\author{
Reinaldo Benedito Nishikawa*
}

RESUMO

O presente artigo pretende analisar os mecanismos utilizados na Província do Paraná na segunda metade do século XIX para converter os imigrantes europeus que desembarcavam no Paraná em cidadãos paranaenses. Sendo assim, a idéia do governo paranaense era fixar os imigrantes e transformá-los em colonos.

PALAVRAS-CHAVE: Imigração. Colonização. Província do Paraná.

\section{ABSTRACT}

This paper analyzes the mechanisms used in the province of Parana in the second half of the nineteenth century to convert the European immigrants who landed in Parana into Parana citizens. Thus, the government's idea was to set Parana immigrants and turn them into settlers.

KEY-WORDS: Immigration. Colonization. Province of Parana.

O período que compreende os anos de 1854 e 1874 pode ser considerado para a Província do Paraná o início oficial de seu projeto de atração de trabalhadores nacionais e estrangeiros. Esse processo se inicia com a formação da Colônia de Assunguy, em 1860, período posterior à independência do Paraná da sua ex-comarca, São Paulo, em 19 de dezembro de 1853. Os novos colonos advindos de todas as partes do Império do Brasil e do mundo, com maior incidência da Europa, podem ser explicados por dois importantes acontecimentos ocorridos em 1850.

Com o fim do tráfico de escravos, promulgado através da Lei Eusébio de Queiroz, a substituição da mão-de-obra escrava teria que ser a longo e médio prazo, solucionada pela introdução de trabalhadores livres. Nesse mesmo ano, em 18 de setembro, foi aprovada a Lei de Terras, com a garantia que sesmeiros, posseiros, grileiros, agregados, dentre outros, não teriam sua propriedade confiscada, nem estariam sujeitos a outros riscos que envolvessem a perda de suas terras. Para a

\footnotetext{
* Docente da Universidade Norte do Paraná. Mestre em História Social pela Universidade de São Paulo. Email. reinaldo1@unopar.br
} 
demarcação e o reconhecimento das terras não existiam prazos imediatos, ficando a cargo do proprietário escolher o momento para tal. O intuito principal de legitimar as posses de terras era para que o governo tivesse um controle do que seriam as terras públicas e as particulares. Nos seus artigos havia a preocupação, também, de atrair trabalhadores para o iminente fim do tráfico de escravos.

Ao tratarmos sobre a colonização e a imigração para o Brasil torna-se importante ressaltar uma periodização. Segundo Cecília Westphalen, o recorte que compreende 1808 até os dias atuais (1969) é considerado como o período de "imigração estrangeira espontânea para o Brasil". No recorte proposto por Westphalen, podemos considerar o período de tempo que se inicia com o fim do tráfico de escravos ao Brasil (1850), e que termina com a crise do café na década de 1930. (BALHANA; MACHADO; WESTPHALEN, 1969, p. 346).

Na Província do Paraná já havia algumas colônias de povoamento e uma colônia militar, instaladas no final da primeira metade do século XIX. Atrair imigrantes não era tão fácil como queriam os diversos interlocutores analisados (presidentes de província, vice-presidentes, ministros, empresários), pois nesse mesmo período, algumas províncias também estavam nessa disputa, sem contar o restante do continente americano. A Província do Paraná criou alguns atrativos para conseguir alocar trabalhadores, sejam imigrantes ou nacionais, que surtiram algum efeito. Nessas colônias os trabalhadores teriam assegurado benefícios e deveriam cumprir certas condições, firmadas diante de um contrato assinado entre o colono e um representante do Estado.

Atrair imigrantes ao Paraná foi o primeiro desafio do governo provincial. Além de atraí-los, o mais importante seria fazer com que esses colonos permanecessem na província.

Quando Wilson Martins escreveu sua obra Um Brasil Diferente, ele expressou essa preocupação salientando que a Província do Paraná deveria ser uma região de carteiras de identidade, uma vez que esses imigrantes ou colonos criariam suas raízes nessa terra, misturando culturas, credos e trabalho com outros habitantes dessa região. O governo provincial tinha que impedir que aqui se tornasse uma parada temporária. Aí a utilização do termo civilização de passaportes.

Então, formar núcleos coloniais tornava-se um desafio, pois toda a América estava buscando esses trabalhadores como podemos observar no livro Fazer a América de Boris Fausto. Esse fazer estava ligado a uma conjuntura que impulsionava pessoas a saírem de seus lares e se aventurarem em outros países. Para que isso acontecesse, se realizou a ação efetiva do Estado e para o caso do Paraná, apresentamos o papel do 
empresário de colonização como crucial para atrair e fixar o trabalhador colono durante a segunda metade do século XIX.

Esses empresários podem ser caracterizados como os antecedentes das empresas de colonização surgidas por capitais estrangeiros no século XX, como por exemplo, a Companhia de Terras Norte do Paraná (CTNP), subsidiária da Paraná Plantations Syndicate, com sede em Londres (ARIAS NETO, 1998). A CTNP veio ao Brasil estimulada pela Missão Montagu, na qual estavam envolvidos técnicos e financistas ingleses. Na mesma época, o governo do Paraná estava oferecendo as terras do norte do Paraná a preços baixos, já que não havia vias de acesso para a região, como estradas de ferro e de rodagem. Por meio dessa companhia surgiram diversas cidades, como Londrina, Maringá, Cianorte, dentre outras.

Assim, entender o papel desses empresários pode nos fornecer algumas perspectivas sobre essa lógica de colonização. Desde o discurso paranista até os significados da Lei de Terras, podemos encontrar o papel desempenhado por esse personagem, vital para a história da imigração no Paraná.

\section{Paranistas}

Na historiografia paranaense da década de 1950, proliferou o discurso de modernidade. Essas novas vozes receberam, de uma geração posterior, a alcunha de "paranistas", assim caracterizados:

Foram eles intelectuais que viveram um "novo surto de desenvolvimento", muitas vezes ligados aos poderes públicos, e que ao perceberem as aparências evidentes, ou ocultas, as avaliaram e registraram. Seus "olhares" não são idênticos: ainda que todos pretendessem o rigor da ciência, colocavam-se em pontos diferentes [...] e se apresentaram como os que não cederam a uma análise ufanista, pautando-se sempre pela seriedade do método. (BURMESTER; PAZ; MAGALHÃES, 1990, p.146)

Para Wilson Martins, que escreve em 1955 o livro Um Brasil Diferente: ensaio sobre fenômenos de aculturação no Paraná, é na extensão das influências dos imigrantes que se pode compreender essa aculturação no Brasil. Uma das tendências marcantes dessa historiografia é tratar os imigrantes paranaenses e suas histórias como grandes epopéias:

[...] como se fosse preciso acentuar desde logo um profissional urbano, que viesse ajudar a estabelecer esta civilização de burgueses e não de marinheiros, de construtores de cidades e não de aventureiros amantes do perigo e da incerteza, civilização da carteira de identidade e não do passaporte. (MARTINS, 1955, p.10) 
Sobre essa afirmação foi criando-se a identidade paranaense. Aliado ao status de trabalhadores fixos em terras paranaenses, essas construções foram ganhando contornos com outros "chamarizes" (clima, fertilidade da terra, vazio demográfico).

Para os migrantes, uma certa dose de fantasia e lenda em torno dos países que os receberiam era necessária. Sérgio Buarque de Holanda relata-nos uma dessas lendas criadas em torno da Província do Paraná para os imigrantes poloneses:

Durante a grande onda de emigração polonesa para o sul do Brasil nos anos que precederam à guerra de 1914-1918, surgiu em certos distritos da Polônia, lenda de que nosso Estado do Paraná acabara de ser descoberto, dissipando-se o denso nevoeiro que durante séculos o envolvera. Foi a Virgem Maria quem, compadecida da sorte dos camponeses da Polônia, lhe apontara a nova terra, dizendo que fossem povoá-la. (DAVATZ, 1980, p.19).

Outra versão da mesma lenda dizia que todos os reis e imperadores da terra fizeram uma assembléia para deliberar a quem caberia a região recém-descoberta. Três vezes apostaram e três vezes saiu vencedor o Papa. Instigado então pela Virgem, o Pontífice entregou o Paraná aos poloneses. (DAVATZ, 1980, p.19).

Baseado nesses argumentos, havia um duplo sentimento em relação ao processo de imigração (PETRONE, 1972). Aos futuros colonos, a prosperidade e a promissão, como tratados no capítulo 1, forjaram lendas em torno da necessidade de migrarem para o sul do Brasil. Por outro lado, a Lei de Terras serviu de suporte, muitas vezes, para legitimar a ação do Estado ou dos empresários de colonização, para atrair imigrantes ao Paraná.

\section{Ensaios de Colonização na Província do Paraná}

Em 01 de março de 1856, o relatório do vice-presidente da Província do Paraná, Henrique de Beaurepaire Rohan, anunciou:

Uma das idéas, que mais prende a attenção publica no Brazil, é certamente a da colonisação. Os meios porêm até agora empregados, para realisal-a, nem sempre tem produzido os mais vantajosos resultados. É meu sentimento, senhores, que a provincia do Paraná, nos seus ensaios de colonisação [...] crêe um estabelecimento agricola, onde se admittão os estrangeiros e nacionaes, que se quizerem sujeitar ao trabalho de parceria, mediante um contracto, pelo qual se obriguem a servir até haverem satisfeito seus empenhos. Estou prontamente convencido que, dirigida a empreza por pessoa intelligente, a provincia tiraria vantagens, que largamente a compensarião das despezas adiantadas. [grifo meu] (BEAUREPAIRE, 1856, p. 38-39). 
Na fala de Beaurepaire Rohan, que dois anos antes fora contratado pelo presidente Zacarias Góes e Vasconcellos para trabalhar como engenheiro responsável pela abertura de novas estradas na Província do Paraná, encontramos alguns pontos interessantes sobre a questão da colonização e sobre a lei aprovada em 18 de setembro de 1850, conhecida como a Lei de Terras. Os meios empregados para realizarem a colonização e a forma como esses empresários conseguiram se articular durante esse processo versam, prioritariamente, sobre a vinda de colonos para a Província do Paraná e sobre essa "pessoa inteligente", responsável por esse propósito.

Temos aqui dois importantes pontos nesse processo. O primeiro aponta para as tentativas de se trazerem colonos para trabalhar nessa província. O segundo ponto trata de quem seria essa pessoa que traria tais colonos para o Paraná? Essa "pessoa inteligente", responsável por trazer esses colonos para a recém fundada província, ficou desaparecida nos trabalhos sobre a Lei de Terras. Chamado pelos relatórios e pelo jornal O Dezenove de Dezembro de empresário, esses sujeitos conseguiram passar despercebidos nesse campo de ação. Mantiveram-se ocultos para os historiadores, uma vez que esses empresários estavam encobertos pelos truísmos acadêmicos de engenheiros, médicos e advogados. Esses empresários mantiveram-se por um bom tempo como os responsáveis por trazer, negociar, controlar e inaugurar colônias de trabalhadores na Província do Paraná na segunda metade do século XIX.

Esses "ensaios de colonização" começaram a serem praticados antes da aprovação da Lei de Terras, como mostram as empreitadas do Dr. J oão Maurício Faivre, da qual falaremos mais adiante. Nesse contexto, esse elemento chamado de "empresário", que surgiu como o responsável por trazer os imigrantes para a Província do Paraná, mantendo diálogo com os presidentes da província, foi agente importante ao lado dos presidentes, dos grandes proprietários, dos pequenos imigrantes e dos brasileiros, na segunda metade do século XIX no Paraná.

O papel desempenhado por esses empresários era o de transformar os imigrantes, das mais diversas partes da Europa, em colonos. Colonos entendidos segundo o significado atribuído pelo Dicionário da Terra:

Membro de uma colônia, pequeno proprietário, trabalhador agrícola, principalmente imigrante ou descendente deste. É um camponês típico, caracterizado pela pequena propriedade rural e que se dedica à produção familiar de subsistência e de mercado, normalmente sem utilização de mão-de-obra externa ao grupo familiar (GREGORY, 2005, p. 102). 
O problema da colonização fazia parte de quase todos os relatórios e falas dos presidentes de província. Com o vice-presidente Henrique Beaurepaire Rohan não foi diferente. Seu primeiro pedido foi conseguir uma autorização do presidente para despender uma quantia de 10:000\$000 anuais para o financiamento de estrangeiros para o Paraná. Essa quantia viria por intermédio da lei provincial no 29, de 21 de março de 1855:

Art. 1o - Fica o governo autorizado a promover a imigração de estrangeiros para esta província, empregando neste sentido os meios que julgar mais convenientes, e preferindo sempre atrair os colonos e demais estrangeiros que já se acharem em qualquer das províncias do Brasil.

Art. 2o - Para que tenha efeito a disposição do artigo antecedente poderá o governo despender anualmente até a quantia de 10:000\$000, além dos reembolsos dos avanços que fizer para passagem e alimento dos imigrantes, segundo os contratos a realizar.

Nessa empreitada, Beaurepaire convidou algumas pessoas que estavam interessadas em trazer colonos para o Paraná. No contrato, proposto entre os empresários e o governo provincial, havia cláusulas que estabeleciam os direitos e as obrigações que deveriam ser respeitadas pelo imigrante interessado em vir à Província do Paraná. Entretanto, tal chamariz não surtiu muito efeito, pois no “[...] prazo de dous mezes, marcado para a apresentação dessas propostas, extinguiu-se, sem que um só empresário houvesse apparecido" (BEAUREPAIRE, 1856, p. 40). O interessante nesse relatório é que uma das justificativas para tamanho descaso era que:

[...] para dar execução áquella lei, já porque não era possível encontrar proprietarios habilitados, para receber, por salário ou parceria, famílias de colonos, já por que a província não tem terras devolutas, onde as receba [...] [grifo meu].

A alegada inexistência de terras devolutas, tal como afirmada na fala anteriormente reproduzida, parece apontar para dois movimentos que começaram em Curitiba e Paranaguá e continuou entre os fins do século XIX e início do século XX para “dentro dos sertões” do Paraná. (ARRUDA, 2000).

Porém, esse movimento de ocupação, não nos permite afirmar a inexistência de terras devolutas, como define o artigo 3oㅡ da Lei de Terras. Segundo Márcia Motta (1998, p. 159-187), que estudou o caso das invasões e disputas entre as terras do Barão de Piabanha e do Barão de Entre Rios e seus agregados, os motivos de se afirmar a inexistência de terras devolutas no Rio de J aneiro foram diversos. Em primeiro lugar, 
deve-se ter claro que era intenção do governo imperial a demarcação de terras para que se pudesse ter uma noção do que seriam as terras públicas em todo o país. Os proprietários não tinham interesse de ver suas terras demarcadas, como salientou a autora. Isso tanto ocorreu que, ao passar o prazo marcado para se fazer o registro de terras, havia um número ínfimo de registros.

Para Lígia Osório Silva, o problema se encontrava em outros aspectos. A abundância de terras aliada a técnicas rudimentares de agricultura levada a cabo pelo trabalho escravo, foi o principal fator do desinteresse em registrar as terras:

\begin{abstract}
A agricultura rudimentar apoiava-se no trabalho escravo e na incorporação contínua de terras novas. Com a desculpa de favorecer a ocupação produtiva do solo, tolerava-se a passagem desenfreada das terras do patrimônio público para o patrimônio privado. Graças à permanência da escravidão as classes dominantes brasileiras não viram motivos para se preocuparem com a delimitação das suas propriedades, nem com o problema da reprodução da mão de obra. Na verdade, na primeira metade do século XIX, o Brasil ainda não se voltara para o seu interior; estava voltado para a África de onde vinham os escravos. (SILVA, 2003).
\end{abstract}

O governo provincial do Rio de Janeiro insistiu em jogar a culpa por esse fracasso nos párocos de cada freguesia, afirmando que estes estavam mais interessados em suas igrejas do que em registrar terras e que essa morosidade era decorrência de má vontade, uma vez que a demarcação dos lotes era de responsabilidade dos J uízes Municipais. Para Motta, as razões para se culpar os vigários eram variadas e, ao mesmo tempo, providenciais, pois eximiam a ineficácia da lei, ao mesmo tempo em que elegiam um bode expiatório:

Para eles [governo provincial], as razões deveriam ser encontradas no papel e na responsabilidade dos vigários, pois alguns deles entendiam que sua missão religiosa os inibia na realização desta tarefa, outros não tinham conhecimento de todos os proprietários de suas freguesias, outros ainda teriam pouco zelo, preferindo declarar que 'não lhe consta haverem pessoas que deixassem de fazer o registro'. (MOTTA, 1998, p.162)

Para além dos comodismos alegados pelo governo provincial, existiam alguns elementos que não constavam nessas reclamações. Certas determinações existentes na Lei de Terras exigiam a participação dos vigários como os responsáveis pelo registro das terras, segundo os artigos 97 e 98 do regulamento de 1854, ou, caso quisessem, contratassem um escrevente que ficariam sob sua responsabilidade. Nessas declarações, de responsabilidade dos vigários, deveriam conter o nome do possuidor da terra, o local de sua freguesia, a situação em que se encontrava a terra, sua extensão e, 
se fossem conhecidos, seus limites. O que não aparece no regulamento sobre a Lei de Terras é que os vigários, além de ficarem como co-responsáveis, por esses registros, seriam também os responsáveis pelo pagamento desses escreventes, caso necessitassem, além de terem que adquirir por conta própria os livros de registro. Visto dessa forma, não parece tão incomum que os vigários ficassem mais interessados em suas obrigações eclesiásticas do que responsáveis pelo registro de terras. ${ }^{2} \mathrm{E}$ caso não os registros tivessem algum problema, como rasuras que prejudicassem a leitura, se houvessem extravios, ou erros que impedissem ver, por exemplo, o tamanho do lote demarcado, os padres teriam que devolver o dinheiro recebido pelo registro além de pagar multa de 50\$ a 200\$, segundo consta no artigo 105 do regulamento.

Nesse ínterim, na Província do Paraná, como de resto já vinha ocorrendo no restante do império, poucas foram as terras consideradas oficialmente devolutas. $\mathrm{O}$ provável local onde se iniciaram as medições e demarcações seria para os lados do Rio Ivaí, do Rio Jatahí e das cidades de Castro e Guarapuava, onde foram fundadas três colônias (Thereza, Jatahi, Superagui), todas por empresários interessados em conseguir trazer imigrantes para essas terras.

Além disso, a inexistência de terras devolutas no Paraná, como afirmava o relatório do vice-presidente, em 1856, ia de encontro a um outro problema que caminhou, lado a lado, com a "ineficiência" dos vigários. Havia o problema de se acompanhar o processo de legitimação das terras e das revalidações das sesmarias. A criação de uma Repartição Geral das Terras Públicas não demorou para funcionar na Província do Paraná, como afirma O Dezenove de Dezembro:

Em officio de 16 do mez p. p. communicou-me o delegado do director geral da repartição das terras publicas Feliciano Nepomuceno Prates, que havendo chegado da corte os empregados, que esperava, começara a sua Repartição a funccionar regularmente.

Também chegou á Província o engenheiro Pedro Toulois, inspector geral da medição e demarcação das terras publicas acompanhado dos agrimensores, desenhadores, escreventes. Necessários para dar começo aos trabalhos de sua commissão, na forma que prescreve o governo imperial em aviso da repartição do império de 12 de março próximo passado, ao qual dei cumprimento, que cabia-me, indicando

\footnotetext{
${ }^{2}$ Conforme expediente do governo provincial, feito em 01 de julho de 1854, editado pelo jornal $O$ Dezenove de Dezembro, em 24 de julho do mesmo ano, em resposta a um vigário sobre os livros de registro: "Pelo seu officio de 19 de junho próximo passado, fiquei sciente de haver vm. recebido a circular desta presidência de 10 de maio, e de que dará fiel cumprimento do capitulo 9 do regulamento de 30 de janeiro último, que lhe foi recommendado. E em solução as duvidas por vm., propostas no referido officio tenho a declarar-lhe, que os livros de que trata o art. 103 do citado regulamento, devem ser comprados a sua vista [...] não estando elles sugeitos ao pagamento do sello, como declara o aviso de 20 de março proximo passado, e nem por consequencia tambem os exemplares das declarações que tem de servir para o registro. (Dezenove de Dezembro, 27 jul. 1854, p. 1).
} 
a localidade que mais propria pareceu-me para dahi começarem os trabalhos de medição. (O Dezenove de Dezembro. 9 maio 1855, p. 2).

Sendo a imprensa um veículo de comunicação vital para a interação entre o governo imperial e seus súditos, devemos levar em conta que as notícias relacionadas com a Lei de Terras foram canalizadas pelo jornal que transmitia ao público as questões sob o ponto de vista oficial, disfarçada sob uma imagem de pretensa neutralidade de interesses. ${ }^{3}$ Pelo menos foi esta a imagem que Cândido Lopes quis passar, a julgar pelas palavras estampadas no primeiro número do seu jornal. Segundo ele,

O Dezenove de Dezembro não hesita [...] na vereda que deve trilhar: o patriotismo [...] que, em sua carreira, [...] cumpre-lhe desempenhar. Este programma é: informar o publico do procedimento do governo da provincia, e das diversas autoridades della, mediante a publicação de seus actos oficiaes [...] aceitando nesse sentido [...] escriptos e informações de quem quer que esteja no caso de lh'os ministrar, abstendo-se completamente de questões políticas. [Grifo meu] (O Dezenove de Dezembro, 1 abr. 1854, p. 1.)

O periódico fez questão de ressaltar sua imparcialidade, apesar de seu proprietário ter um longo contato com o presidente da província Zacarias Góes e Vasconcellos e, um ano após sua chegada ao Paraná, Cândido Lopes tornar-se promotor público de Curitiba. De qualquer maneira, o jornal conseguiu apresentar a Lei de Terras como algo benéfico à população e que garantia o direito de propriedade aos atuais donos e, ao mesmo tempo, afirmava ser necessária tal medida para que se fizesse cumprir a regulamentação dos governos provinciais e imperiais.

O caminho trilhado pelo proprietário d'O Dezenove de Dezembro assemelha-se muito com o do vice-presidente Beaurepaire. Ambos vieram à Província tão logo esta se tornou independente de São Paulo: um como jornalista, outro como engenheiro. Anos mais tarde, já apareceriam diretamente ligados aos órgãos oficiais e burocráticos da Província do Paraná.

Por pedido do vice-presidente da Província ao ministro do império, as colônias receberiam uma ajuda financeira para continuarem suas atividades, mas foram feitas

\footnotetext{
${ }^{3}$ Como afirmou o proprietário do periódico sobre as vantagens da aprovação da Lei de Terras, é possível perceber, ao menos, que as razões do reconhecimento das terras particulares, era de interesse fundamental ao proprietário de terras, que a providente lei vinha auxiliá-lo nas possíveis invasões, evitando possíveis e demoradas decisões jurídicas. "Pelo que fica exposto se vê o processo a seguir-se para se reconhecerem todas as terras que estão no domínio particular, e por tanto as que ficão sendo consideradas devolutas. A lei e o regulamento são de uma excessiva generosidade; reconhecem o direito que qualquer razão possão allegar os occupantes de terras. Até hoje as terras, ainda que medidas, demarcadas, e julgadas por sentença, não estavam livres de invasão, e os proprietários erão obrigados ou a tolerarem o esbulho que lhes fazião os invasores, ou a se lançarem nos azares de uma longa,
} 
algumas exigências por parte do ministro. Primeiro, as colônias teriam que ser constituídas em um espaço de pelo menos oito léguas quadradas de terras devolutas e livres de contestação. Segundo: deveriam ser atravessadas pela estrada que ligava Curitiba a Antonina. Terceiro, a terra deveria ser produtiva e exigia-se que se produzisse em abundância milho, feijão e batatas e, em quarto lugar, ter uma certa garantia de que essa colônia teria possibilidades de, mais tarde, tornar-se uma vila ou cidade próspera, seja pelo comércio, pela lavoura ou pela agricultura. (BEAUREPAIRE, 1856, p. 41)

\begin{abstract}
Dadas as circumstancias acima apontadas, e encarregando-se a provincia de promover a importação dos colonos, e supprir-lhes o que pudesse ser necessario, no primeiro anno, depois de sua chegada, o governo imperial faria medir e demarcar uma sufficiente porção de lotes urbanos e rusticos, que serião aforados, com pequenissima retribuição, aos mil primeiros colonos que chegassem; e auxiliaria a sua importação, por intermédio dos ministros e consules brasileiros na Europa, e por outros quaesquer individuos, que mais proprios julgasse, para tal fim, e mesmo subvencionaria a provincia do Parana com a somma de 20U000 rs., por cada individuo de idade de 12 a 15 annos, e com a de $15 U 000$ rs., pelos que tivessem de 5 até 12 annos exclusive (sic)
\end{abstract}

O diálogo entre o ministro do império - responsável por garantir a permanência dos imigrantes - e o governo provincial - destinado a aceitar esses imigrantes, distanciavam-se em um ponto importante. Segundo o relatório de 1856, não havia espaço para alocar esses imigrantes:

\begin{abstract}
A este aviso tive a honra de responder que não ha, nem á direita, nem á esquerda da estrada da Graciosa, uma área de 8 leguas quadradas de terrenos devolutos, e que, portanto, não havia possibilidade de se poder effetuar o estabelecimento da colonia, do modo indicado por S. Ex .

Devo aproveitar a opportunidade, para declarar-vos, senhores, que Guilherme Stager, natural de Suissa, e cuja moralidade me affiança o Dr. Faivre, veio ultimamente a esta provincia, no intento de formar um estabelecimento colonial, especialmente destinado á cultura do trigo. Assegurei-lhe que a presidencia não deixaria de proteger a sua empreza, com todos os meios a seu alcance. Esperançado deste modo, foi á procura de sua familia, que se acha no Rio de Janeiro, e com a qual deve brevemente voltar a esta provincia. Se forem convenientes as garantias que offerecer, mui provavel é que a presidencia, no interesse da industria agricola, consiga ver fundada nesta provincia uma colonia á guisa da de Ybycaba, e que, como ella, seja a expressão da nossa hospitalidade e boa fé. (BEAUREPAIRE, 1856, p. 42).
\end{abstract}

dispendiosa e quasi sempre interminavel demanda.” (Editorial do Dezenove de Dezembro, 6 abr. 1854, p. 2-4). 
Mais uma vez surge no relatório o nome de um personagem, o Dr. Faivre, cujo nome parecia inspirar confiança ao vice-presidente da Província do Paraná. Suas empreitadas, descritas no livro Saga da Esperança de Josué Corrêa Fernandes, descreve-o como uma figura quase mítica, a: "[...] façanha desbravadora do grande herói do livro, o idealista francês doutor J ean-Maurice Faivre”.(FERNANDES, 2006). E cuja experiência em formar colônias e trazer imigrantes, antecedem em anos a aprovação da Lei de Terras. Com sua aprovação, tornou-se possível conseguir um incentivo a mais para trazer esses imigrantes apoiando-se na falta de mão-de-obra para o trabalho pesado.

\begin{abstract}
A escassez de trabalhadores para o serviço das estradas, mesmo para o daquella (a Graciosa) que considera-se necessidade vital da provincia, a repugnancia que mostrão a esse serviço os poucos sujeitos capazes de nella empregar-se, são conhecidas de todos [...]". (GÓES E VASCONCELLOS, 1855, p. 31)
\end{abstract}

Sabemos que, para além da falta de trabalhadores para os serviços necessários à recém criada província, a vinda de imigrantes deixaria outros segmentos da sociedade bastante satisfeitos (PETRONE, 1982). Segundo Lígia Osório Silva, havia dois tipos de imigração, que, todavia, apontavam para propostas incompatíveis, a saber, a imigração regular ou subvencionada pelas autoridades brasileiras. (SILVA, 1996, p.128) Incompatíveis, na sua visão, porque estas duas propostas procuravam atender interesses opostos. De um lado, o governo imperial; de outro, os grandes proprietários. A imigração regular forneceria subsídios para que o governo conseguisse dinheiro para amortizar a imigração subvencionada. A imigração subvencionada daria, para os proprietários, condições para impor uma relação de dependência com o imigrado. O governo lucraria com o dinheiro do colono que poderia comprar seu lote de terras com suas próprias economias. Os proprietários ganhariam com a dependência do imigrado para conseguir pagar seu lote através do trabalho em suas terras. (MARTINS, 1990).

Apesar dessas propostas incompatíveis, governo e proprietários estavam mantendo uma relação de interdependência com esses empresários da colonização. Não importava se a imigração fosse imigração subvencionada ou regular: a existência desses agentes no processo de colonização garantiria o fluxo contínuo de imigrantes. Vejamos as estratégias utilizadas por esses empresários para conseguirem seus propósitos.

Em 1855, Henri Doge Wylep veio para a Província do Paraná para escolher um lugar ideal para fundar uma colônia. A princípio, sua intenção era de fundá-la entre 
Cananéia e Iguape, construindo uma estrada entre esses dois pontos que se ligaria a Curitiba.

Através dos mecanismos propiciados pela Lei de Terras, Henri Wylep pediu ao governo, segundo consta no relatório do presidente da província, que ao abrir a estrada por conta própria, de aproximadamente dez léguas, a “concessão gratuita de cinco léguas quadrada por cada légua de estrada”.(GÓES E VASCONCELLOS, 1856, p.28). Pediu também a venda de outro igual numero de léguas de terreno na serra,

[...] pelo preço mínimo da lei n. 601 de 18 de setembro de 1850, com a clausula de realisar o pagamento de 10 annos depois da respectiva medição e demarcação feita nos termos da mesma lei..

O governo, como consta, indeferiu sua solicitação dizendo ser exagerado e absurdo tal pedido “[...] oposta á lei, alem de versar sobre terrenos que a repartição geral das terras publicas tem em conta de excellentes para serem reservadas afim de se tirarem madeiras appropriadas á construção naval".

O que Henri Wylep fez, no intuito de trazer imigrantes europeus para iniciar uma nova colônia foi, em parte, assegurar através de uma interpretação bastante peculiar da Lei de Terras e seu Regulamento (MOTIM, 1987; GUTIÉRREZ, 2001), um número considerável de terras que margeariam todas as 10 léguas de estrada que as ligavam a capital da Província. Levando-se em conta, segundo Benilde Motim no caso do Paraná e Márcia Motta sobre o Rio de Janeiro, que as medições feitas pelos “[...] senhores de terra [que] tendiam a apresentar a extensão apenas da testada de sua fazenda, eximindo-se de declarar a extensão pelos fundos e pelos lados”,(MOTTA, 1998, p. 168) o terreno pedido para doação por Henri Wylep era algo em torno de uns 60.000 metros quadrados, além de um igual número que adquiria por preço considerável, apoiando-se no artigo 14 da Lei de Terras. ${ }^{4}$

No que consta dos relatórios dos presidentes da Província do Paraná, tentativas como as de Wylep foram constantes. No mesmo ano, M. Barandier andou procurando

\footnotetext{
${ }^{4}$ Art. 14. Fica o Governo autorizado a vender as terras devolutas em basta pública, ou fora dela, como e quando julgar mais conveniente, fazendo previamente medir, dividir, demarcar e descrever a porção das mesmas terras que houver de ser exposta à venda, guardadas as regras seguintes: § 1. A medição e divisão serão feitas, quando o permitirem as circunstâncias locais, por linhas que corram de norte ao sul, conforme o verdadeiro meridiano, e por outras que as cortem em ângulos retos, de maneira que formem lotes ou quadrados de 500 braças por lado demarcados convenientemente. § 2. Assim esses lotes, como as sobras de terras, em que se não pudor verificar a divisão acima indicada, serão vendidos separadamente sobre o preço mínimo, fixado antecipadamente e pago à vista, de meio real, um real, real e meio, e dois reis, por braça quadrada, segundo for a qualidade e situação dos mesmos lotes e sobras.
} 
um lugar apropriado para fundar uma colônia na província do Paraná. O Dr. Recksteimer, um homem já conhecido em Paranaguá onde exercia a profissão de médico, procurou o presidente para conseguir certos benefícios para trazer uma família da Suíça, composta de nove pessoas, "[...] todas dos melhores costumes [...]" para estabelecer-se nessa província, procurando "[...] saber que favores poderia esperar da respectiva presidência”. (GÓES E VASCONCELLOs, 1855, p. 29). Como resposta, o presidente ofereceu locação e boas-vindas aos imigrantes que poderiam estabelecer-se na Colônia Thereza. O Dr. Recksteimer não aceitou estabelecer-se na Colônia Theresa porque a família não queria "[...] ir para o Yvahy, preferindo ao sertão o litoral [...]", além disso, pediu “[...] a certeza de alguma subvenção para indemnisar as despesas da viagem da Europa ao Rio de Janeiro, e da Corte a Antonina ou Paranaguá". Seu pedido foi recusado, e como resposta, o presidente da província constatou que:

O alto preço das passagens da Europa para o Brasil, comparativamente á diminuta somma porque os colonos conseguem transportar-se de seu paiz aos estados da União anglo-americana, é talvez um dos mais consideráveis obstáculos á emigração de Europeos; que tanto havemos mister; e assim não deixaria de ser muito efficaz, no sentido de attrahir colonos á província, a medida de consignar-se em lei uma somma para auxiliar as despezas de passagem ao menos até o ponto de annular a enorme differença entre o preço de transporte para a União e para o Brasil. (GÓES E VASCONCELLOS, 1855, p.30)

Esses dois exemplos parecem ser sugestivos para ampliarmos nossa noção sobre os problemas, tensões e conflitos no que tange à efetivação da Lei de Terras e das diferentes "leituras" que foram feitas dela.

Na província do Paraná, os problemas decorrentes da falta de trabalhadores para os serviços necessários, como a abertura e construção de estradas feitos pelo governo provincial ou pelos empresários, assim como a mão-de-obra para trabalhos na agricultura e nos demais afazeres que necessitavam a província, eram escassos, como salienta Andreazza e Nadalin (1994, p. 66): “[...] a elite brasileira como um todo supunha que a presença estrangeira e os descendentes que pudessem gerar constituiriam importante fator para o povoamento do território e, ao mesmo tempo, para o desenvolvimento da agricultura".

Uma das soluções apresentadas pelo relatório do presidente da província no ano de 1855 era que “[...] se a polícia não interviesse, constrangedo-os a irem, por escala, trabalhar, mediante os salários convenientes, não haveria no mez uma semana de trabalho". A solução novamente era trazer trabalhadores imigrantes nas "[...] férteis 
terras de Yvahy, obrigados a pagar, em praso estipulado, o dinheiro que se lhes adiantasse".(ibidem)

Até 1856, havia na Província algumas colônias constituídas, a saber: Colônia do Rio Negro, fundada em 6 de fevereiro de 1829. Essa foi a primeira colônia a se constituir no Paraná. Em 1828, no dia 30 de junho, saiu do Porto de Bremen o navio veleiro Charlotte Louise, a caminho do Brasil, terra que se mostrava promissora diante de notícias enviadas para a Europa.Os imigrantes desembarcaram em Antonina e no dia 6 de fevereiro estavam em Rio Negro, onde ficaram em verdadeiro estado de abandono. Foi destinada aos primeiros colonos a região localizada cerca de $36 \mathrm{~km}$ da costa da atual capital, o núcleo da Província São Pedro de Alcântara.

Em seguida, destacamos a Colônia Militar do Jatahi,(BOUTIN, 1977, p.13-67) fundada entre a margem do Rio Tibaji com o Rio J ataí, de responsabilidade do diretorcomandante Thomaz J osé Muniz e do capelão Frei Mathias de Genova. Contando na época com 100 pessoas, o diretor afirmou que não conseguiu aumentar a produção da colônia pois "[...] a maior parte dos engajados não tem a necessaria aptidão, para empregar-se, e desempenhar os serviços e trabalhos della, uns por velhos, outros por defeitos physicos, e outros, enfim, por estarem aferrados á vadiação”. (BEAUREPAIRE, 1856, p.43)

A segunda colônia, chamada de Superaguy, foi fundada em 1852 por Carlos Perret Gentil, J orge Carlos Melly e Augusto Perret Gentil. A colônia era formada por 10 famílias suíças, 5 francesas e 2 alemãs, num total de 64 pessoas. Essa colônia também não estava conseguindo se manter, como informa Carlos Perret Gentil. Segundo esse diretor, entre os anos de 1852 e 1856, essa empreitada teria custado aos cofres da Província 50:000U000 rs. O interessante dessa colônia é que adotou o sistema de parceria à moda da Colônia Ibicaba, do Senador Vergueiro (HOLANDA, 1972). Carlos Gentil Perret havia escrito o livro A Colônia Senador Vergueiro em 1851. Esse sistema de parceria significava para Sérgio Buarque de Holanda, uma prerrogativa:

A vantagem principal do regime de parceria, comparado ao dos serviços assalariados, está aparentemente no fato de garantir, ao menos em tese, uma liberdade mais ampla ao empregado e em reduzir ao mínimo possível conflitos de tradições, costumes e convenções. (DAVATZ, 1980, p. 29).

Finalmente, talvez a única que conseguiu prosperar - Colônia Thereza fundada em 1847 pelo Dr. João Mauricio Faivre. No período de sua fundação, constavam 79 franceses mas “[...] quasi todos se retirárão, desanimados pelas difficuldades, que encontrárão naquelle sertão [...]”. Em compensação, o número de 
colonos brasileiros aumentou consideravelmente, vindos dos municípios de Castro e Guarapuava. Em 1856, havia 19 franceses e 171 brasileiros. Essa colônia conseguiu manter-se e chegou a exportar seus excedentes, dentre eles, cana, café, tabaco, algodão, arroz e frutas, somando todas as exportações em 6:040U000 rs. A Colônia Theresa interligou-se com a vila de Guarapuava, graças a estrada aberta pelo Dr. Faivre, que foram, sem dúvida, motivo de preocupação para todos na Província, uma vez que elas ligariam as cidades, vilas e colônias, servindo para o transporte de mercadorias e de pessoas, como a estrada da Graciosa, cuja importância acabou sendo motivo de notícias veiculadas pelo jornal da província. Veremos, mais adiante, alguns desses debates sobre da estrada da Graciosa.

As construções de estradas na Província do Paraná feitas por empresários facilitariam o trabalho do governo provincial, uma vez que os eximia das responsabilidades e custos dessas empreitadas, mas por outro lado, permitia que esses empreendedores tivessem meios para negociar algum benefício com os presidentes da Província. Ao que tudo indica, essas práticas de "troca de favores" era comum no Império do Brasil. Segundo Luiza Iotti (2005, p. 185-213), essa era uma das formas dos presidentes das províncias conseguirem seus cargos, além, é claro, da lealdade demonstrada ao imperador. Essas relações entre o governo e os empresários trariam vantagem a ambos, além de que, a colonização poderia ajudar o governo a coibir o problema das invasões de terras, como alertava o presidente Gomes Nogueira:

A segurança [...] de propriedade, esse - bem - que se torna apreciada pela ausência ou diminiução dos crimes e que uma sociedade organisada deve sem distinç̧ão de classe ou nacionalidade outorgar á todos os seus membros, está longe ainda entre nós de tocar a méta marcada pela civilização e progresso. (NOGUEIRA, 1863, p. 6).

Esse incentivo para a entrada de imigrantes parece ter surtido algum efeito, apesar das dificuldades encontradas por muitos que vieram em busca da "terra de sonhos" prometida pelos empresários. Ao menos é o que mostram as entradas e saídas de estrangeiros na Província do Paraná. Segundo o número oficial, entre os anos de 1862-1863 entraram na Província cerca de 1.009 pessoas, entre imigrantes, leia-se europeus e brasileiros, além de estar registrado a entrada de 62 escravos. Nesse mesmo período, saíram sem destino apontado, 556 imigrantes europeus, 418 brasileiros e 76 escravos. Desses escravos, não há notícias ou informações de sua procedência.

Dois anos antes, em 1861 registrou-se a entrada de 881 imigrantes, 491 brasileiros e 102 escravos. Saíram, 889 imigrantes, 487 brasileiros e 124 escravos. Esse número mostra um equilíbrio entre o número de pessoas e, ao mesmo tempo, sua 
circularidade. O número permanece praticamente inalterado, mas o fluxo contínuo entre os que entravam e saiam pode dar margens a um grande número de interpretações. Primeiro, não devemos considerar totalmente confiável esses números por tratar-se de algo de difícil domínio, uma vez que esse serviço era precário e sem nenhum grande controle. Segundo, esses registros destinavam-se a apresentar um certo controle das pessoas que viriam ao Paraná, apontando para o máximo de estabilidade possível. Destarte, pode ser que não tenha sido a permanência dos imigrantes que garantiu a legitimidade dos empresários de colonos ao Paraná, mas a constante necessidade de manter um número mínimo de pessoas dispostas ao trabalho. No que tange ao número de escravos, basta lembrar que em 1850 é extinto o tráfico no Brasil e, segundo Robert Slenes, acentuou-se o tráfico entre as províncias, numa tentativa de suprir as necessidades das regiões que utilizavam mão-de-obra escrava. (SLENES, 1999).

O contínuo fluxo de imigrantes para o Paraná, aliado à morosidade das medições, exigia um número considerável de pessoas destinadas a demarcação, medição e regulamentação das terras. Na Província do Paraná foi instaurada a inspetoria de medições de terras, sob responsabilidade do engenheiro Theodoro Ochsz, do escrivão Américo Alves Pinto de Mendonça e dos agrimensores Roberto Ziemssem e Luis Henrique Barão Holleben em 1858, conseguindo demarcar, medir e legalizar terrenos destinados a criação de colônias em Assunguy (anexo 02), que foi a primeira colônia a ser criada logo após a emancipação da província do Paraná de São Paulo, da aprovação da Lei de Terras e da ação dos empresários de colonização:

\begin{abstract}
Acham-se medidos no Assunguy tres territorios inteiros e cinco perimetros de territorio, sendo aquelles subdividos em lotes de 250 mil braças quadradas.

Todo o terreno medido occupa uma superficie de 32 leguas quadradas, abrangendo cada perimetro e cada territorio a extensão de duas leguas de frente e outras tantas de fundo; ficando apenas o quarto perimetro á Oeste: todo o mais terreno medido á Leste da primeira meridiana (9o 18' 4" O de Greenwich) e o segundo e terceiro perimetros á Sul, o resto porem á Norte da base principal (24 $53^{\prime} 33^{\prime \prime}$ 7 latitude Sul). (MATTOS, 1858, p. 32).
\end{abstract}

Nesses termos, essa repartição, criada para a demarcação das terras devolutas, conseguiu, segundo consta, legitimar 46 posses de terras, com uma extensão de 26 milhões de braças quadradas. Desses, dois terços estavam sendo utilizados na plantação de grãos, o restante, reservado para o cultivo da erva-mate e da criação de gado. 
O segundo territorio do Assunguy acha-se completamente descriminado, existindo nelle encravadas 12 posses particulares devidamente legitimadas na conformidade do aviso de 10 de Abril de 1858; podendo o governo dispôr de todo o resto do dito territorio sem prejuizo de particulares. (MATTOS, 1858, p. 32).

Pode-se apreender desta fala que as medições estavam sendo feitas, apesar da morosidade e dos empecilhos acima comentados. Além disso, havia na Província do Paraná uma preocupação em se dar conta dessas terras, a fim de evitar brigas, "[...] como também para prevenir questões, rusgas e as vezes crimes graves entre os particulares". (MATTOS, 1858, p. 32). Parece-nos bastante claro que as tentativas do governo provincial em legitimar as posses estavam sendo minadas desde o final do prazo marcado pela Lei de Terras para o registro de terras dos proprietários. Mesmo assim, o governo insistia nessa questão, apesar das limitações e dificuldades para tal empreitada, até porque sem demover este obstáculo não conseguiria implantar efetivamente a lei.

\begin{abstract}
As legitimações até hoje effectuadas na provincia limitam se quasi, sem excepção, todas ao municipio de Curityba, e bem que ainda um certo numero de requerimentos pedindo legitimações, se ache em poder do juiz, muitas terras ainda ha no município que estão sujeitas á mesma formalidade, sem os seus donos a terem requerido; talvez por descuido ou indolencia ou o que é mais provavel, renitencia senão falsa supposição, de que nenhum prejuizo pode-lhes resultar da inobservancia dos ditos preceitos da lei. (MATTOS, 1858, p. 32).
\end{abstract}

O que destoa quando se fala nesse período, em trabalhos como o de Márcia Motta no Rio de J aneiro, é que a autora afirma haver um declínio da Lei de Terras com o passar dos anos. Analisando os relatórios dos presidentes da província do Rio de J aneiro, Motta destacou que “[...] aos poucos [...] o otimismo manifesto nos primeiros relatórios oficiais daria lugar à crença de que a Repartição Geral de Terras Públicas teria sérias dificuldades em se firmar como órgão responsável pela discriminação das terras públicas das particulares”. (MOTTA, 1998, p. 162). No Paraná, os relatórios conseguiram se manter por um pouco mais de tempo às pressões existentes. A recémcriada província parece ter procurado despender mais esforços para tentar impor novamente, o registro das terras particulares.

No ano de 1858, o governo provincial baixou uma outra resolução, impondo um último prazo para que as terras fossem legitimadas, encerrando o prazo em agosto de 1859, caso contrário, utilizando do artigo 58 da Regulamentação da Lei de Terras, os donos que não requeressem o registro, veriam suas terras colocadas em "comisso" 
perdendo o proprietário qualquer direito a ela. A princípio, essa resolução se restringiria a Curitiba, mas com a vinda de mais juízes e comissários para a Província, essa resolução espalhar-se-ia para as demais localidades. Até porque, não se poderia afirmar, garantiu o presidente da província, que:

[...] esta medida seja iniqua ou injusta, porque a unica desculpa que podia haver para este deleixo dos particulares, seria a grande pobreza em que se acham.

O governo imperial porem, tendo previsto este caso, mandou, por aviso de 10 de abril de 1858, que nesta hypothese as legitimações se fizessem por conta delle, como de facto já varias vezes se tem praticado nesta provincia.

É de esperar-se que o povo do Paraná mais e mais se convencerá da necessidade e vantagens que devem resultar da execução desta a mais essencial parte da lei das terra, que diz respeito a discriminação territorial entre os particulares e o governo.

A lei de terras é um grande triumpho da moral publica sobre o egoismo individual e sem contradicção o mais bello e constante monumento da actividade creadora do parlamento, do governo brasileiro, e especialmente do então ministério Mont'Alegre. (MATTOS, 1858, p. 35-36).

Mas apesar do esforço do governo provincial essas medidas surtiram pouco efeito, levando-se em conta que em 1863 haviam sido registrados 75 posses de terras.

Mesmo com a garantia do governo de pagar a demarcação, caso o proprietário não tivesse condições para tal, poucos seguiram essa recomendação. Seja pelo desconhecimento da lei, seja por comodismo ou por qualquer outro motivo, a Lei de Terras transformou-se numa disputa entre os diversos personagens para garantir benefícios próprios, utilizando-se de alguns dos termos da Lei de Terras quando essas lhe trouxessem benefício.

Em 21 de março de 1860, começou-se na Província, por ordem do governo imperial, a demarcação das terras devolutas em Assunguy, na tentativa de se evitar invasões. Essas demarcações abririam espaço para a ação dos empresários. Esses homens conseguiram encontrar uma brecha na Lei de Terras para introduzir imigrantes e, ao mesmo tempo, lucrar com isso. Empreendedores, com boas relações entre os presidentes, conseguiram prosperar através da Lei de Terras. Seus propósitos seguiram as diretrizes oficiais da província. Conseguiram sucesso, onde outros fracassaram, perderam e arriscaram, como fez Dr. Faivre ao abrir estradas entre sua colônia e Curitiba. Uns conseguiram seus pedidos, outros não. Alguns exigiram terras em troca de trazerem imigrantes. Mas o que é possível perceber no que tange ao "ensaio de colonisação" e todos os mecanismos movidos pela Lei de Terras e sua 
regulamentação é que os responsáveis pelo contato entre o país de origem dos imigrantes e do governo provincial não são muito lembrados nessa questão.

E longe de querer dimensionar demais o empresário de colonização, como central na participação da vinda de imigrantes, ele nos permite vislumbrar outros agentes em disputa em torno da Lei de Terras, que para alguns historiadores foi vetada pelos barões, para outros, não passou de uma lei que garantiu o poder dos grandes proprietários, outros ainda, conseguiram ver na lei a participação do pequeno proprietário, do posseiro e do grileiro como agentes atuantes numa relação recíproca, ainda que desigual. Nesse embate de forças, apresentar outro participante, que também conseguiu valer-se de direitos vem enriquecer o debate a respeito da imigração e da Lei de Terras, que longe de se esgotar, tem um longo caminho a ser percorrido.

\section{A Lei de Terras e Seus Significados}

A Lei de Terras e seu regulamento serviram para discriminar o domínio público do particular na tentativa de se regularizar a estrutura fundiária no país. Entretanto, isso dificilmente daria fim às brigas envolvendo a questão da terra, seus limites imprecisos e a sua ocupação. Essas questões complementam uma importante lacuna nas questões das posses de terras devolutas, mas é importante ressaltar que a regulamentação das terras devolutas, feita pelos proprietários, encontrava um importante aliado com a Lei de Terras. O proprietário ao registrar os limites de suas terras não necessitava provar legalmente a forma de aquisição, bastando nomear os limites existentes, geralmente com limites geográficos (uma pedra, um rio) ou com outros proprietários, que por sua vez, garantiriam a legitimidade de sua propriedade.

Encontramos dois importantes relatos publicados, ambos, em 1854, no jornal O Dezenove de Dezembro, que expressam suas opiniões contrárias a Lei de Terras. O primeiro deles, de autoria de J esuíno Marcondes de Oliveira e Sá, colocava em questão a validade e eficácia da vinda de colonos à Província do Paraná. Publicado na sessão intitulada Publicação a Pedido, o escritor pagava para ver publicada suas críticas, sugestões, boas-vindas e despedidas. Essa sessão assistiu durante três semanas as críticas de J esuíno, que recebeu opiniões contrárias a suas idéias, inclusive do próprio dono do jornal.

Em circular do dia 20 de dezembro de 1853, publicado pelo jornal O Dezenove de Dezembro, o presidente da província, Zacarias Góes e Vasconcellos, escreve ao Dr. J oão Mauricio Faivre 
[...] declare-me o seu pensamento relativamente aos meios de aqui promover-se o augmento d'aquella população, indicando os que lhe parecerem mais acertados, ou consistão na creação de núcleos de colonisação estrangeira [...] para o que apontará as localidades mais apropriadas por seus recursos e condições de salubridade [...]. (O Dezenove de Dezembro, 1 abr. 1854, p.3.).

Nessa circular, o presidente apresentou suas considerações e demonstrou a credibilidade que o Doutor Faivre possuía na província. Tendo fundado sua primeira colônia em 1847 a Colônia Thereza, - homenagem a imperatriz Thereza Cristina - o Doutor Faivre já era conhecido de todos os importantes políticos na província. Nessa circular, Zacarias Góes pedia auxilio para que encontrasse um lugar propício para a fundação de novas colônias na província. Seu prestígio era tanto que:

J ean-Maurice acentua ao presidente Zacarias que os dois grandes trunfos da Colônia Thereza são, justamente, a magnífica posição e o fim com que foi instalada. No plano de colonização que concebeu, teve em mira não apenas prestar auxílio aos infelizes e órfãos da sorte. Quis, também, construir algo de vantajoso ao País, introduzindo a indústria agrícola e a moralidade 'que parece aí estar em falta'. Em razão disso é que se manteve afastado do 'mar', onde a ganância tem acarretado tantos desastres e sofrimentos inúteis. Reconhecendo que ainda não atingiu plenamente os objetivos, tem convioção, todavia, de que já conseguiu algo em favor da dignificação das pessoas, ao solicitar ao Imperador D. Pedro II que ficasse proibida a escravidão nos domínios da Colônia, o que foi aceito sem qualquer imposição. (FERNANDES, 2006, p.167).

Entretanto, segundo matéria paga pelo Sr. J esuíno Marcondes de Oliveira e Sá, no jornal O Dezenove de Dezembro, a empreitada de trazer imigrantes para trabalhar na Província não daria muitos resultados. Divididos em três partes, publicadas consecutivamente entre os dias 3, 10 e 24 de junho de 1854, a carta manifestando idéia contrária a vinda de imigrantes começava elogiando o empenho do governo imperial e os incentivos de pessoas preocupadas com a vinda de trabalhadores para a província, mas que, infelizmente "[...] parece [me] assás difficil a realisação de colonisação nesta província, por quanto bem sérios embaraços tem de encontrar essa idéa esperançosa".(O Dezenove de Dezembro, 3 jun. 1854, p.5-6). Difícil por dois motivos em particular. Primeiramente porque o

[...] commércio e a creação de animaes são as industrias dominantes: a agricultura é mais uma imposição da necessidade de que uma fonte de riquezas; portanto esta mina inexaurível é apenas explorada pela parte mais pobre de população à quem falta absolutamente outro meio de vida; e mesmo assim, desde que se podem forçar ao trabalho das terras, tomão outro norte immediatamente. 
Em segundo lugar porque a província do Paraná “[...] é somente rica de esperanças e de elementos de grandesa ainda em embrião, tem falta de capitaes [...]", que seria a condição primária para qualquer empresa industrial, principalmente a agricultura, “[...] que só vagarosamente remunera os avanços feitos [...]”. Assim sendo, as tentativas de trazer colonos para trabalhar no Paraná não encontraria espaço para o desenvolvimento de nenhum tipo de indústria. Mesmo sabendo das possíveis conseqüências devido ao fim do tráfico de escravos em 1850, J esuíno declarou ser imatura a vinda de trabalhadores.

O governo do paiz sente a aproximação de uma crise, que será fatal, se, de longe não for prevenida, e por isso secundará seguramente os esforços dos homens novos, de idéas esclarecidas, e vedores do futuro, que abraçarem um pensamento que tem tanto de bello quanto de util, formando desde já um nucleo de esforços que não pode deixar de produzir muito bons resultados. (O Dezenove de Dezembro, 3 jun. 1854, p. 6.).

Essa crise, além de contar com a falta de braços escravos para o trabalho, não respondia a uma outra realidade existente na Província. Segundo J esuíno, as possíveis indústrias que dariam certo no Paraná seriam a da erva-mate. No entanto, por ser de pouco valor, em nada valeria continuar tal empreitada.

O matte, como planta indigena, poderia ser considerado como o producto mais vantajoso para a exploração, por quanto temos grandes florestas onde o arbusto que presta para este chá, cresce espontaneamente deixando ao homem, apenas o trabalho da colheita; todavia me abalançarei a dizer que esta industria não offerece um futuro duradouro, e que actualmente mesmo só é sustentada pelos hábitos rotineiros do nosso povo pobre, que continua a empregar-se em um trabalho quasi profícuo, que no fim do anno lhe produz seguramente menos que o salário de um jornaleiro. (O Dezenove de Dezembro, 3jun. 1854, p. 6)

Além do mais, a região de Curitiba estava em desvantagem em relação a outras províncias

O Paraná não tem a vantagem dos grandes viais fluviais como o Amazonas, nem um territorio geralmente chato como o Rio Grande do Sul; suas vias de communicação, ainda atrasadas, tornão o transporte demorados e caros; mas alem de seu clima quasi europeo, de seu diminuto numero de escravos, a providente natureza, para suavizar a tarefa do colono, estendeo um immenso sertão de mattas ferteis por ambos os costados do Serra do Mar. (O Dezenove de Dezembro, 3jun. 1854, p. 6)

Mas qual seria a intenção de J esuíno ao insistir que as indústrias no Paraná não dariam grandes resultados. No que tange a sua leitura de Lei de Terras, segundo ele 
próprio afirma, seria conveniente a vinda de trabalhadores para a agricultura pois a fertilidade da terra traria população laboriosa e repovoaria todo o Paraná (IANNI, 1972). Sendo assim:

\begin{abstract}
A execução da lei de terras e o poder da conveniencia farão brevemente refluir a população que buscava fortuna nos sertões longinquos para a repovoação de nossos terrenos já occupados, e para as terras ainda devolutas que jazem no meio delles encravados. $(\mathrm{O}$ Dezenove de Dezembro. 24 jun. 1854, p. 9).
\end{abstract}

Suas investidas nos permitem averiguar a situação da província em relação ao seu desenvolvimento industrial. Pouco era seu entusiasmo com as possíveis indústrias que viriam junto com os colonos, mas a agricultura traria um novo fôlego aos "sertões longínquos" que seria repovoado. Mas repovoado implica na existência de outros nas terras. Seriam posseiros, sesmeiros ou índios? Todos esses personagens poderiam explicar sua simpatia pela execução da Lei de Terras.

No caso desse (re)povoamento implicar na existência de posseiros, grileiros ou sesmeiros em terras particulares, o interesse em se legitimar a propriedade privada traria benefícios para ele próprio. Ao afirmar que a região de Curitiba não seria um bom lugar para se trazer colonos, implica que os "sertões" seria o lugar onde essas pessoas melhor se adaptariam. Com os férteis terrenos e grandes espaços para se plantar, a (re)povoação seria benéfica para todos.

J esuíno era defensor da idéia de que apenas deveriam ser trazidos agricultores ao Paraná (PEREIRA, 1998, p. 5). Tinha interesse em manifestar-se pela aprovação da Lei de Terras, mesmo sabendo das dificuldades enfrentadas pela recém criada província e das possibilidades existentes para se extrair algum lucro com a (re)povoação do Paraná. Além disso, seu nome aparece diversas vezes nos expedientes provinciais como participante de várias comissões criadas pela província do Paraná. Entre os anos de 1854-1855 fez parte das Comissões de Constituição, J ustiça e Força Pública e da Comissão de Instrução e Catequese de Índios, tornando-se anos mais tarde, o presidente da província. Mas vejamos o caso de M. A de Paula para podermos inferir algum sentido nessas manifestações publicadas n'O Dezenove de Dezembro.

Para melhor entendermos as manifestações de Jesuíno, é preciso voltar novamente ao grande empresário de colonos, o Dr. J oão Mauricio Faivre, que em 1854, acabara de voltar da Corte onde havia negociado subsídios para trazer novos imigrantes a Província do Paraná como mostra as notícias de Cândido Martins Lopes publicadas n’O Dezenove de Dezembro. 
Chegou a dias a esta cidade, vindo da corte de S. M., J oão Mauricio Faivre. Acolhido benignamente pelo governo de S. M. em suas pretensões, o dr. Faivre pode obter do mesmo governo a celebração de um contracto muito favoravel a seus fins humanitários na colonia Theresa sobre o Ivahi, de que elle é o digno director. (O Dezenove de Dezembro, 10 jun. 1854, p. 2).

A volta do Dr. Faivre foi recebida com grande entusiasmo pelo proprietário do jornal O Dezenove de Dezembro e pelo presidente da província Zacarias Góes e Vasconcellos. Ao que tudo indica, o Dr. Faivre foi à Corte conseguir algum capital para sua colônia e voltou com suas expectativas renovadas. Mas, em troca das benesses concedidas ao Dr. Faivre, o governo imperial exigiu algumas condições. Entre elas, que na sua colônia se ocupasse da catequese indígena, de modo a assegurar o salvamento de almas selvagens e garantindo a cristianização desses gentis homens. Além dessa "boa ação", cabia ao Dr. Faivre, além da já estabelecida Colônia Theresa, fundar mais duas colônias, onde melhor lhe conviesse, como já foi pedido pelo presidente Zacarias Góes.

O terceiro pedido do governo imperial era a de abrir estradas na província através dessas colônias, fazendo com que elas se interligassem, e que de preferência, passassem por Curitiba.

Dirigida por uma pessoa tão digna como o dr. Faivre, é de suppor que a colonia Theresa, com a protecção que acaba de receber do governo imperial, assuma em breve tempo o mais alto gráo de prosperidade compativel com a sua situação, vindo a ser como um phanal brilhante plantado no deserto, irradiando a luz da civilização por aquelles remotos lugares.

Entretanto, como a fundação das colônias e a construção de estradas que facilitariam o acesso dessas com Curitiba e demais vilas, algumas pessoas começaram a questionar certas práticas, como construir determinada estrada e não outra. Foi o que fez o sr. M. A. de Paula.

O segundo nome que aparece é de M. A. de Paula, que criticava a existência de uma comissão destinada a abrir uma estrada, a da Graciosa, sob a responsabilidade do tenente coronel de engenheiro Henrique de Baurepaire Rohan, função exercida na província de 1854-1855, tornando-se um ano depois vice-presidente da província do Paraná. Mas as críticas feitas por M. de Paula levantavam uma discussão sobre a validade de se construir uma estrada - a da Graciosa - que traria benefícios apenas aos grandes proprietários de terras e outras pessoas de prestígio na província. Ao invés disso, M. de Paula sugeria a construção da estrada de Itupava, que garantiria ser mais benéfica, menos onerosa e muito eficiente aos verdadeiros paranaenses. Seja como for, 
essas duas críticas podem nos dar uma margem para se entender esse engenhoso processo ocorrido na província do Paraná. Vejamos esses dois casos.

A longa discussão que gerou os comentários de M. Paula com o folhetinista da Revista Mensal do Dezenove de Dezembro, além de outros leitores do jornal, como o sr. F. B. de Castro, centrava-se no empenho do engenheiro Beaurepaire na construção da estrada da Graciosa por ordem do governo provincial. M. de Paula, insistentemente dizia ser mais vantajoso ao "povo do Paraná" a construção da estrada de Itupava:

Se o governo tem em vistas abrir uma via de communicação mais commoda á alguns particulares, ahi está á estrada da Graciosa, se ao contrario quer crear uma artéria tangente com todas as veias, que do cerebro vá ao coração com igual sensibilidade dos membros latentes, não trepide em adoptar a estrada de Itupava. (O Dezenove de Dezembro. 1jul. 1854, p.6.).

Essa via mais cômoda aos particulares pode ser referência ao Dr. Faivre que tinha como obrigação construir algumas estradas e que, por "coincidência", a estrada da Graciosa cruzava a Colônia Thereza, fundada pelo Dr. Faivre. Até esse ponto o questionamento levantado pelo sr. Paula é perfeitamente plausível, e foi tão contundente que "Américus" o folhetinista d'O Dezenove de Dezembro gastou dois dias na publicação de sua Revista Mensal para travar discussão com o sr. Paula.

Antes de propiciarmos a nossa tarefa mensal, julgamos de rigoroso dever dizer duas palavras sobre um artigo publicado pelo Dezenove de Dezembro em um número passado, e assignado pelo sr. M. A de Paula, relativamente as estradas de Itupava e da Graciosa. A nenhuma das duas estradas demos então preferência, assim como abstivemo-nos, receiosos de antecipar juízos temerários, de fallas das novas picadas operadas pelos engenheiros em suas excursões. (O Dezenove de Dezembro, 1 jul. 1854, p. 1).

O tom do folhetinista seguia as diretrizes propostas pelo jornal. A imparcialidade expressa em seu primeiro número continuava nas palavras do folhetinista. Mas apesar dessa suposta imparcialidade as acusações trocadas entre o folhetinista e M. A. de Paula estavam centradas nos interesses conflitantes em que ambos defendiam. O folhetinista estava ao lado do engenheiro Beaurepaire e da construção da estrada da Graciosa. Assim também defendidos pelo leitor F. B. de Castro. Infelizmente, é impossível saber quem era esse leitor e qual interesse teria na defesa da construção da estrada da Graciosa. Só podemos supor que ele poderia se beneficiar dessa estrada de algum modo, seja por ser proprietário ou comerciante que teria alguma vantagem com a nova estrada, ou por fazer parte do aparelho burocrático 
da província, que em nada destoaria de sua posição, muito pelo contrário. Entretanto, o sr. Paula insistiu durante muito tempo sobre essa questão.

[...] emprehendendo esta publicação, sentimos ter de contestar o autor da Revista Mensal do Dezenove de Dezembro, cujo talento devia ser empregado em cousas mais justas para apparecer no quadro das intelligencias que operão por impulso proprio; sim, porque cremos de boa fé que o illustre redactor tem sido mal informado.

Em um comunicado publicado pelo jornal, dizia que "O Sr. M A de Paula, do Porto de Cima, na noite de 5 do corrente, as 11 e meia horas, recolhendo-se para sua casa, foi accomettido por um individuo chamado Manoel Dominiciano, que armado de cacete, conseguiu partir-lhe o frontal e fazer-lhe algumas contusões no braço esquerdo [...]". (O Dezenove de Dezembro. 15jul. 1854, p. 4.)

Depois dessa notícia, publicada uma semana depois de sua última carta redigida ao jornal, M. A de Paula não mais escreveu para o jornal, e durante todo o ano de 1854 não se teve mais notícias de seu paradeiro, nem dos motivos do acusado Manoel Dominiciano ter atacado a vítima. Ao que parece, o sr. Paula havia tocado em alguns pontos nevrálgicos existentes entre o presidente da província e o Dr. Faivre, no que concerne a vinda de colonos ao Paraná, mas que, por hora, não passam de suposições.

Em 15 de junho de 1854, o relatório do presidente da Província do Paraná, Zacarias de Góes e Vasconcellos, alertou:

Agitão-se frequentes questões de posses e limites, que em geral procedem do estado confuso e desordenado da propriedade territorial, as quaes, no futuro he provavel se reduzão á pouco ou nada, com a observancia da lei das terras e respectivos regulamentos, que, procurando definir e fazer conhecida a porção de terra, de que cada hum he proprietario, tendem a assegurar á todos o gozo de seus direitos sem o temor de força do vizinho, nem da conta do escrivão e do advogado ás vezes mais damnosa. (VASCONCELLOS, 1854, p. 4).

Na fala do presidente, as questões relativas a legitimidade das posses das terras estavam centradas no texto da Lei de Terras que garantia a legalização e o reconhecimento das terras por parte dos proprietários. Notadamente, “[...] assegurar á todos o gozo de seus direitos [...]" reflete mais a necessidade de assegurar a propriedade de alguns.

É preciso ressaltar que de acordo com os termos da Lei de Terras, a propriedade da terra somente se concretizaria quando se efetivasse a sua legalização. Portanto, o processo jurídico de apropriação da terra foi a via pela qual assegurou-se o direito sobre a propriedade e, conseqüentemente, criou as condições para transformá-la em 
mercadoria no processo geral de circulação de bens. De acordo com a Lei de Terras, a terra só se tornaria instituição jurídica quando se tivessem os títulos de propriedades outorgados na esfera do judiciário. Assim, a hipótese que direciona esta reflexão histórica é a de que a passagem da posse para a propriedade da terra é uma transformação que se coloca no espaço do jurídico. (MOTTA, 1998, p. 110).

A disputa centralizou-se na demarcação e regulamentação da terra. Ao Estado coube criar mecanismos para a efetivação e legitimação da propriedade territorial através de aparelhos jurídicos, além de servir como responsável por resolver disputas e conflitos entre proprietários de terras e posseiros. A Lei de Terras veio para tentar solucionar esses problemas, além de ser uma tentativa de separar as terras devolutas das particulares. Para os proprietários, a grande ação centralizava-se na sua propriedade de terras e na ação de eventuais posseiros.

Os principais artigos da Lei de Terras inauguraram, no sistema jurídico, a venda das terras públicas como seu único acesso e a garantia do direito de propriedade. Os documentos onde os artigos da lei são enunciados repetem esse mesmo principio, inexistindo qualquer menção ao contrário, como se não houvessem discussões nem discordâncias. Essa aparente "paz" foi capaz de silenciar outras vozes nesse processo. Entretanto, algumas vozes ecoaram dentro dessa esfera, como a de M. A de Paula e J esuíno Marcondes Oliveira e Sá, que conseguiram resistir dentro de suas realidades e necessidades próprias.

Após intensos debates, a Lei de Terras foi finalmente aprovada em 1850. Entretanto, a preocupação com a possível falta de braços escravos para o trabalho não foi o único motivo para a aprovação da lei. Devemos nos questionar sobre dois pontos principais. Primeiramente, se houve a necessidade de se criar uma lei que garantisse a legitimidade da terra e o direito de propriedade, é porque havia uma preocupação real em garantir a propriedade. Mas porque? Se o "veto dos barões" não foi suficiente para garantir sua posse é porque a "invasão do vizinho" ultrapassava o poder do proprietário. Em segundo lugar, devemos pensar no problema da leitura sobre a Lei de Terras, pois essa lei estava esboçada de modo que permitiria diferentes interpretações e com isso acabou se convertendo em terreno prolífico para decisões judiciais cada vez mais abrangentes.

Se a lei significou a tentativa de substituir a mão-de-obra escrava através da imigração, assim como, significou a segurança da propriedade privada dos grandes latifundiários, ou mesmo dos pequenos "invasores", fossem eles posseiros, grileiros ou agregados das fazendas, alguns conseguiram através dos mesmos mecanismos criados pelos grandes "barões”, lograr a lei e transformá-la em arma para coibir mecanismos 
que impossibilitavam seu acesso à terra. Desse modo, a Lei de Terras propiciou através de suas diferentes interpretações, uma forma de burlá-la. No caso dos empresários de colonos, alguns conseguiram através da Lei de Terras, benefícios para suas empreitadas na formação de colônias, outros não tiveram tanta sorte, mas o fato fundamental dessas tentativas é demonstrar que a Lei de Terras propiciou diversas leituras e interpretações de seus artigos e regulamentos. A Lei de Terras foi considerada como "letra morta" pela incapacidade de fazer com que seus termos fossem cumpridos. Por outro lado, o fim da mão-de-obra escrava não teve grandes efeitos na província, uma vez que os colonos não iriam substituir a mão-de-obra escrava, mas formavam núcleos coloniais com a possibilidade de tornar-se também proprietário de terras. Além disso, os empresários e suas "amizades" com o governo provincial foram, muitas vezes, decisivas para o sucesso ou fracasso das primeiras colônias fundadas no Paraná.

\section{Referencias}

ANDREAZ7A, Maria; NADALIN, Sergio. O cenário da colonização no Brasil Meridional e a família imigrante. Revista Brasileira de Estudos Populacionais, Campinas, v. 11, n.1. 1994.

ARIAS NETO, J osé Miguel. O Eldorado: Representações da política em Londrina 1930-1975. 2.ed. Londrina: EDUEL, 1998.

ARRUDA, Gilmar. Cidades e Sertões:- entre a Memória e a História. Bauru: Edusc, 2000.

BALHANA, Altiva Pilatti; MACHADO, Brasil Pinheiro; WESTPHALEN, Cecília Maria. Alguns aspectos relativos aos estudos de imigração e colonização. São Paulo, 1969.

BOUTIN, Leônidas. Colônias Militares na Província do Paraná. Boletim do Instituto Histórico, Geográfico e Etnográfico Paranaense, v. 33, , p. 13-67, 1977.

BURMESTER, Ana Maria; PAZ, Francisco; MAGALHÃES, Marionilde. O Paranismo em Questão: o pensamento de Wilson Martins e Temístocles Linhares na Década de 50. In: SILVA, Marcos (Org). Repúblicas em Migalhas: história regional e local. São Paulo: Marco Zero, 1990.

DAVATZ, Thomas. Memórias de um colono no Brasil. São Paulo. Edusp, 1980.

FERNANDES, J osué Corrêa. Saga da Esperança. Curitiba: Imprensa Oficial, 2006.

GUTIÉRREZ, Horacio. A estrutura fundiária no Paraná antes da imigração. Estudos de História. Franca, v. 8, n. 2, 2001, p. 209-231.

HOLANDA, Sérgio Buarque. As colônias de parceria. In: Civilização Brasileira. São Paulo: Difusão Européia do livro. 19̄7̄. $\bar{t}$.2, v. 5.

HOLANDA, Sérgio Buarque. Prefácio. In: DAVATZ, Thomas. Memórias de um colono no Brasil. São Paulo. Edusp, 1980. 
IANNI, Octavio. O progresso econômico e o trabalhador livre. In: HOLANDA, Sérgio Buarque (org). História Geral da Civilização Brasileira. São Paulo: Difusão Européia do livro. 1972. t. 2, v. 5.

IOTTI, Luiza Horn. Presidentes da província: a leitura oficial dos imigrantes italianos no Império. Revista Métis, Caxias do Sul, v. 4, n. 8, p. 185-213, 2005.

MARTINS, J osé de Souza. O Cativeiro da Terra. 4. ed. São Paulo: Hucitec, 1990.

MARTINS, Wilson. Um Brasil diferente: ensaio sobre fenômenos de aculturação no Paraná. São Paulo: Anhembi, 1955.

MATTOS, Liberato de. Relatório do Presidente da Província do Paraná. Curityba: Typ. Paranaense de Candido Martins Lopes, 1858.

MOTIM, Benilde Maria. Estrutura fundiária do Paraná tradicional. Castro, 18501900. Dissertação (Mestrado em Historia do Brasil) - UFPR, Curitiba, 1987.

MOTTA, Márcia Maria Menendes. Nas Fronteiras do poder: conflito e direito à terra no Brasil do século XIX. Rio deJ aneiro: Vício da Leitura, 1998.

NOGUEIRA, Gomes. Relatório do Presidente da Província do Paraná. Curityba: Typ. Paranaense de Candido Martins Lopes, 1863.

PEREIRA, Magnus. Tess não veio a Curitiba. Revista Monumenta. Imigração para o Brasil. Ponta Grossa, p. 5, 1998.

PETRONE, Maria T. Schorer. O imigrante e a pequena propriedade. São Paulo: Brasiliense, 1982.

PETRONE, Teresa Schorer. Imigração Assalariada. In: HOLANDA, Sérgio Buarque (Org). História Geral da Civilização Brasileira. São Paulo: Difusão Européia do livro. 1972. t. 2, v. 5.

ROHAN, Beaurepaire. Relatório do Vice-Presidente da Província do Paraná. Curityba: Typ. Paranaense de Candido Martins Lopes, 1856.

SILVA, Ligia Osório. Na terra, a raiz do atraso. História Viva, São Paulo, n. 1, nov. 2003.

SILVA, Lígia Osório. Terras Devolutas e Latifúndio - Efeitos da Lei de 1850. Campinas: Unicamp, 1996.

SLENES, Robert. Na senzala uma flor. Rio de J aneiro: Nova Fronteira, 1999.

VASCONCELLOS, Zacarias Góes e. Relatório do Presidente da Província do Paraná. Curityba: Typ. Paranaense de Candido Martins Lopes, 1855.

VASCONCELLOS, Zacarias Góes e. Relatório do Presidente da Província do Paraná. Curityba: Typ. Paranaense de Câdido Martins Lopes, 1856. 